\title{
sciendo
}

\section{Factors determining company performance in the IT industry}

\author{
Miruna Florina LUNGU \\ Bucharest University of Economic Studies, Bucharest Romania \\ lungu.miruna@gmail.com
}

\begin{abstract}
The dynamics of the business environment indicate that companies should become more flexible and value oriented. The competition within the IT sector leads to increased uncertainty for the players and a higher focus on the strategic direction of the company. Hence, many studies point out the significance of strategic agility as a tool of increasing company performance and achieving improved results. The paper highlights how the performance of IT companies is impacted by various factors. The main driver for company performance is strategic agility mixed with absorptive capacity. For a better understanding, the paper will analyze knowledge acquisition, knowledge assimilation, transformation and knowledge exploitation. These four dimensions represent the layers of absorptive capacity. Using as framework a survey developed based on the literature, there will be performed an analysis of the input received. The responses have been captured from stakeholders of the IT industry, who are employees of IT organizations with operations in Romania. For an enhanced output, there will be applied a regression analysis. This will contribute to the identification of factors determining company performance in the IT industry. The results of the regression analysis will demonstrate that strategic agility, knowledge acquisition and transformation have the highest impact on company performance. As only three out of the five tested dimensions are validated, further research can be grounded on understanding why knowledge assimilation and knowledge exploitation have not been confirmed as factors impacting company performance.
\end{abstract}

Keywords: Company performance, strategic agility, IT, knowledge acquisition, transformation.

Please cite the article as follows: Lungu, M.F. (2020), "Factors determining company performance in the IT industry", Management \& Marketing. Challenges for the Knowledge Society, Vol. 15, No. 1, pp. 59-77. DOI: $10.2478 /$ mmcks-2020-0004.

\section{Introduction}

The business environment is in a continuous process of change, so companies are constantly looking to different ways of improving their performance. The paper aims to identify and acknowledge the factors leading to increased company performance with the help of strategic agility. Having as starting point the relevant literature on the topic of strategic agility, the paper will deep dive on what strategic agility stands for. Further on, it will define which are the factors leading to company performance and test the impact for each dimension. Using the literature as a foundation, a series of hypotheses will be developed with the support of hypothesis testing. Once defined, these will be tested using statistics analysis. The tests applied within the paper include Pearson's correlation, Durbin-Watson, ANOVA analysis, analyzing standardized and unstandardized coefficients and testing the collinearity of the variables. The outcome of each test is detailed under the Results and Discussion sections of the paper. Once all analysis is conducted, the paper will outline that only three out of the five hypotheses are supported. The three validated dimensions will be strategic agility, knowledge acquisition and transformation. 
The paper's focus will be on a real case study of the IT sector, gathered by the author by using primary research. Firstly, it consists of a survey built as per validated sources of the literature. The analysis section will be based on the input collected by the author from stakeholders of IT companies operating in Romania. The data has been primarily collected by the author through a survey shared with the respondents in 2019. It includes questions triggering the factors of company performance. For creating the survey, the author included five survey sections with questions covering: the sample, strategic agility, absorptive capacity, IT and company performance.

The paper aims to search and identify the most relevant factors leading to increased performance for companies of the IT sector in Romania. The findings of this paper have as objective a better understanding of the company performance. This will be addressed in the context of strategic agility together with validating other key factors leading to increased company performance in the Romanian IT sector.

\section{Literature review}

Nowadays the competition on the business environment is becoming more powerful. According to Bolisani and Bratianu (2018) knowledge and strategic thinking enable the achievement and maintenance of the competitive advantage. Srivastava and Sushil (2013) mention that strategic agility is a way of adapting and at the same time maintaining competition alive. As per Oyedijo (2012), strategic agility takes place on different company layers: organizational, technological and human. Hence, companies must always be focused on being dynamic and flexible to internal and external changes. Păunescu et al. (2018c) argue in their paper that companies must have a business continuity plan. Weber and Tarba (2014) mention that globalization, technological advancement and resource mobility are only some of the factors contributing to the dynamism of the business environment. Di Minin et al. (2014) define strategic agility as a company's ability to adapt to the changes of the business climate, having as key objective the integration of strategic objectives and enhanced performance. Doz (2019) considers that strategic agility represents an outcome of performance resulted from strategic initiatives of the company.

According to Ali et al. (2016) companies use absorptive capacity and innovation as a transformation process in order to boost their performance. Absorptive capacity is defined as the ability to capture the value of new insights, assimilate and put them into practice. On the other hand, organizational innovation is an ability to improve on different organizational layers such as: product, process and management.

Ramos et al. (2013) believe IT represents a path for new opportunities and an increased success level. Flatten et al. (2011) consider strategic agility to be a mediator between absorptive capacity and company performance. Nemkova (2017) supports that the use of strategic agility leads to enhanced performance. Garcia et al. (2017) add that there is a strong link between IT and innovation. The authors highlight that strategic agility is a matter of proactivity. This is defined as the ability to drive change in a strategic way. Doz (2019) sustains the same idea, adding that to reach strategic agility, the company must adopt a flexible and consistent strategic thinking. McIver et al. (2018) confirm that flexibility is a feature of strategic agility together with speed and continuous change. Moreover, Srivastava and Sushil (2013) add that there is a relationship between strategic thinking and strategic agility. 
Hacklin et al. (2018) argue in their paper that in the IT and telecom industries there has been a constant change regarding industry's leaders. The authors consider strategic agility to be a trigger for gaining and securing a strategic position on the market. Doz and Kosonen (2010) add the fact that dramatic shifts of business models in the IT industry take place because of shifts in customer demand. Ammar and Chereau (2018) consider that adapting to the customer's demand can be perceived as a double-sword approach. This means that it can provide a first mover advantage, but it can also influence an organization to lose its primary business focus. As per Vecchiato (2015), having a first mover advantage through strategic agility represents a way of building value inside the market. Junni et al. (2015) believe that strategic agility is an enabler for building a competitive advantage. Nemkova (2017) confirms that strategic agility is significant for reaching a competitive advantage and increased company performance on the market. Further on, Mclver et al. (2018) support the idea that strategic agility involves continuous change. Păunescu et al. (2018c) add that companies must have a business continuity plan, namely these should have a strategic approach in foreseeing their future on the market. Hacklin et al. (2018) bring into discussion the mechanism of firm-market matching. The authors see it as a way of reaching strategic agility. The term describes a concept by which internal resources and capabilities are linked with external market conditions. Firm-market matching takes place only if a transfer of value exists. Alahyari et al. (2017) strengthen the significance of strategic agility as a way of maximizing value and increasing company performance. Bratianu and Bolisani (2015) sustain that value creation is important in strategic thinking. Further on, Di Minin et al. (2014) add that strategic agility impacts economic value creation and secures long-term survival on the market. Battistella et al. (2017) support value as an embedded component of strategic agility. Vecchiato (2015) consider that strategic agility is a way creating value. Păunescu et al. (2018b) agree that improved performance can be reached through transparency among the actors of the company.

Doz (2019) believes that in the case of the IT sector, strategic agility represents a key factor for performance. Thus, in IT companies there is an increased need of strategic agility to keep and boost performance. Kim and Chai (2017) outline that strategic agility contributes to improving company performance. Further on, Wilden et al. (2013) define dynamic capabilities as processes that enhance superior performance for a company. Teece (2018) add that dynamic capabilities are agile processes of sensing and seizing opportunities. Zahra et al. (2006) argue that dynamic capabilities are rooted in the strategic agility of the company. The authors support Doz and Kosonen (2010)'s definition on strategic agility, described as the ability of a company to react to business climate changes and adapt to change. Kim and Chai (2017) agree that strategic agility is a response to the changes of the business environment. On the other hand, Shin et al. (2015) bring a new perspective over strategic agility. The authors believe it is more than a capability, but rather an integrated strategy or a management practice. Yang and Liu (2012) add that companies use strategic agility to identify and react to changes of the industry and at same time keep their focus on improving their performance.

Kale et al. (2018) describe strategic agility as a connector for absorptive capacity and company performance. Absorptive capacity involves the search of new commercial chances. The mix between strategic agility and absorptive capacity is viewed by the authors as leading to improved company performance. 
Kale et al. (2019) study further on a three-dimensional model: strategic agility, absorptive capacity and firm performance. Absorptive capacity is defined as the ability to acknowledge the value of novelty and make use of it. The authors describe that absorptive capacity includes four pillars: knowledge acquisition, knowledge assimilation, transformation and knowledge exploitation. Tallon et al. (2011) have discovered that absorptive capacity mediates the relationship between strategic agility and company performance. With the use of the four pillars, absorptive capacity becomes a mediator for reaching company performance. Lane et al. (2001) test and validate that absorptive capacity is significantly positive with the performance of the company. Oyedijo (2012) confirm the significance of the relationship between strategic agility and company performance. The author highlights that companies with high focus on strategic agility are outperforming the ones with lower commitment to strategic agility.

For a better understanding, the paper will briefly describe the meaning of each of the four pillars of absorptive capacity. As per Kale et al. (2019) knowledge acquisition refers to the capacity to identify and acquire external knowledge. Bratianu (2015) shares the same view, defining knowledge acquisition as an ability to capture the flux of external knowledge. Once the knowledge is acquired, knowledge assimilation arises. The authors describe it as the ability of analyzing and understanding the new captured information. The next pillar of absorptive capacity, transformation, is described as a connector between existing and new knowledge. On top of that, Kale et al. (2019) define the fourth pillar of knowledge exploitation as an enabler to develop and bring innovation based on what has already been transformed. Păunescu et al. (2018a) add that in the case of change, one must also consider sustainability in the decision-making process.

\section{Methodology}

\section{Hypotheses development}

Many studies of the literature indicate that there is a connection between strategic agility and company performance. At the same time, absorptive capacity is perceived as a leant between the two concepts. According to Kale et al. (2018) absorptive capacity has four layers: knowledge acquisition, knowledge assimilation, transformation and knowledge exploitation. Step by step in the paper there be will defined a hypothesis for each of these dimensions.

The paper's analysis is focused on five hypotheses which have been defined using exploratory research. It consists of the literary research and analysis of the input received, outlined below by figure 1 .

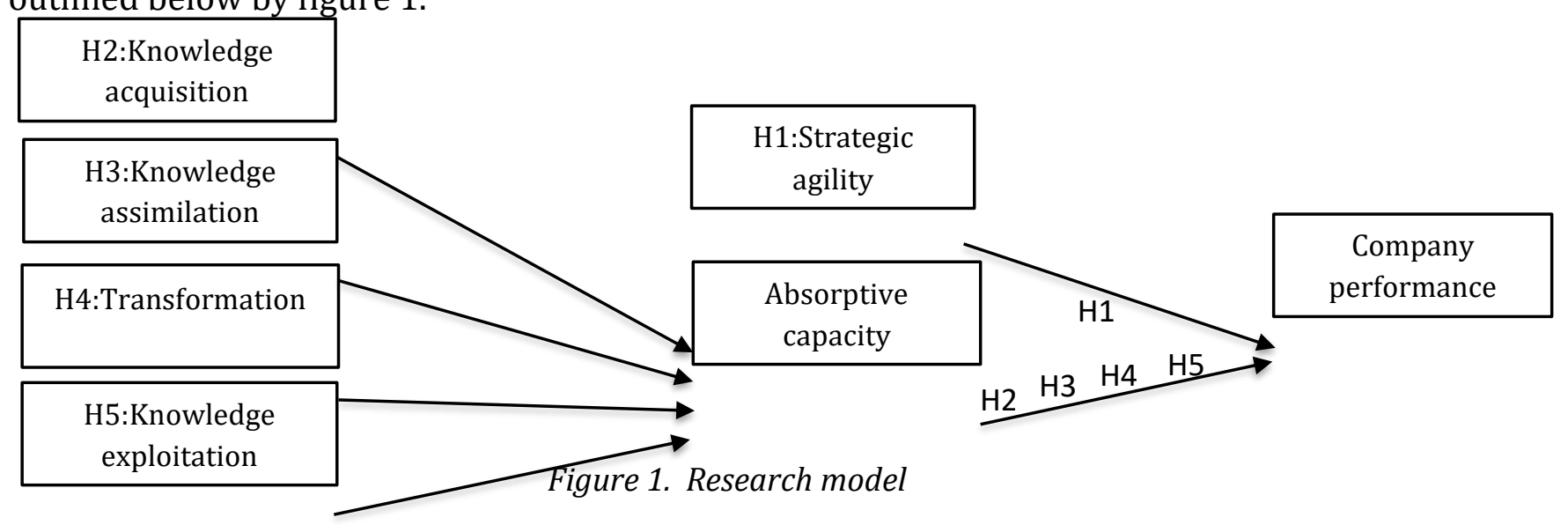

Vol. 15, No. 1, Spring, pp. 59-77, ISSN 2069-8887| Management \& Marketing. Challenges for the Knowledge Society 
Below, there have been listed each of the five hypotheses to be tested using a regression model.

Hypothesis 1. Strategic agility is positively related to company performance.

Tallon et al. (2011) study the influence of strategic agility with a company. The authors have tested their hypotheses on performance, concluding that agility is positively associated with company performance. They add that there is relationship between agility and company performance. Quiroz et al. (2018) consider that IT is a dynamic factor generating strategic agility, which increases the company performance. One of the hypotheses tested by the authors mentions that strategic agility mediates the company performance. The authors prove that the hypothesis is supported, validating that company performance is enhanced by strategic agility through IT. Kale et al. (2018) conclude as well that strategic agility positively impacts company performance.

Hypothesis 2. Knowledge acquisition is positively related to company performance.

Queiroz et al. (2018) define knowledge acquisition as the ability of acquiring external knowledge from the market. Bratianu (2015) mentions that knowledge acquisition is impacted by absorptive capacity and the business environment. As indicated at the beginning of the paper, knowledge acquisition is an embedded part of absorptive capacity. One of the Kale et al. (2018)'s validated hypothesis states that strategic agility is a mediator between absorptive capacity and company performance. Knowledge acquisition proves to have an indirect role in influencing the performance of the company. Navarro et al. (2016) mentions that there is positive relationship between knowledge acquisition and knowledge conversion. As this hypothesis is supported, the authors indicate that acquiring strategic insights from external sources leads to enhanced agility.

Hypothesis 3. The higher the knowledge assimilation is, the higher the company performance is. Flatten et al. (2011) position knowledge assimilation as a second layer of absorptive capacity. Kale et al. (2018) claim that knowledge assimilation takes place by developing an analysis process of understanding the acquired external knowledge. What is being assimilated is used for current and future incentives of improvement. Hence, one can state that knowledge assimilation influences the performance of the company. Baker et al. (2017) outline that the speed of assimilating external knowledge has a positive impact on company performance.

Hypothesis 4. The higher the transformation of the company is, the higher the company performance is.

Shin et al. (2015) see transformation as a mandatory survival technique to stay competitive on the business environment. The authors claim transformation is a path for strategic agility leading to positive influence over the company performance. Battistella et al. (2017) sustain that transformation helps managers on setting the strategic direction of the organization for increased performance. Further on, Hacklin et al. (2018) outline that in the IT industry, innovation and transformation are key paths a company should embrace in order to increase its performance level. 
Hypothesis 5. There is a statistically significant effect of the knowledge exploitation on the company performance.

Flatten et al. (2011) define knowledge exploitation as the final step of absorptive capacity, namely the commercial pillar for achieving company performance. The authors describe knowledge exploitation as the ability to apply new insights and embed them in the company's routine. On the other hand, Lavie and Rosenkopf (2006) view knowledge exploitation as a tool for developing capabilities already known and extracting the best from these. Teece (2018) considers that a company can become more competitive not only by exceling at sensing new opportunities, but at implementing and exploiting them. Păunescu et al. (2018b) argue in their research about the implementation of an ISO standard in Romanian companies. The authors mention that adopting and implementing an idea are related are fundamental for developing a company.

\section{Research Objectives and Method}

The paper aims to analyze the determining factors leading to company performance. The defined objectives of the paper are the following: (1) to understand the factors influencing company performance; (2) to identify the key drivers of performance; (3) to find out if a certain variable can predict company performance in the context of the IT industry.

A quantitative research has been carried out on the Romanian IT companies. Using an anonymous questionnaire, the data has been collected by the author in the period December 2018 - October 2019. The questionnaire is available at this link. The selection of the sample for the survey had to align to certain terms. One of the criteria the respondents had to meet, refers to the fact that they must be part of a multinational IT company, operating in the capital city of Romania. Further on, the representatives of the companies participating to the survey had to be employed in an IT company, holding a technical or non-technical role inside the organization with a seniority of at least one year. The author has managed to gather 100 valid responses using snowball sampling. This technique has enabled existing respondents to recruit future ones from their professional group. Given so, there have been captured the responses of IT professionals from Romania, employed in various departments in IT companies: finance, operations, engineering, management and so forth.

According to Taherdoost (2016) the survey represents an effective way to collect data and the most challenging part is to capture relevant responses. The author sustains the consistency and relevance of the sample. Wright and Stein (2005) mention that snowball sampling should be used as the preferred method to capture real-life behaviors. Illenberger and Flötteröd (2012) add that in snowball sampling the objective is to capture relevant data. The authors add that the sample size should be decided by the researcher and should be based on consistency. Snowball sampling is more objective as it is not constrained by a firstdegree relation between the researcher and the sample. The literature advises that researchers should focus on obtaining relevant responses in a survey, without defining a specific sample size to be appropriate as a framework. Thus, the author managed to capture 100 valid responses, relevant to the current research, with the note that the outcome of the study cannot be generalized to the entire business environment.

The data has been collected through an online survey, using Google Docs. The questions comprising the survey have been addressed in a structured way. These have included five sections as follows: sample understanding, measuring strategic agility using Tallon and Pinsonneault (2011), absorptive capacity using Flatten et al. (2011), IT and 
strategic agility questions and company performance questions, using Queiroz et al. (2018). Each of the sections aimed to identify the respondents' opinion related to the paper's defined objectives.

\section{Measures}

As mentioned above, the survey has been adopted from previous studies of the literature. It has been developed by using validated measures from other research surveys. The survey has been refined to strategic agility, the four absorptive capacity pillars and company performance. These have been illustrated in the table 1 below.

Table 1. Survey questions and sources

\begin{tabular}{|c|c|c|}
\hline Variable & Question & Source \\
\hline Strategic agility & $\begin{array}{l}\text { The company responds to changes in aggregate consumer demand. ( e.g. it } \\
\text { embeds digital fingerprint unlock for a smartphone) } \\
\text { The company customizes a product or service to suit an individual customer. ( } \\
\text { e.g launch a product on a customized color) } \\
\text { The company reacts to new product or service launches by competitors. } \\
\text { The company introduces new pricing schedules in response to changes in } \\
\text { competitors' prices. ( e.g black Friday pricing policy) } \\
\text { The company expands into new regional or international markets. } \\
\text { The company changes (i.e., expand or reduce) the variety of products / } \\
\text { services available for sale. } \\
\text { The company adopts new technologies to produce better, faster and cheaper } \\
\text { products and services. } \\
\text { The company switches suppliers to avail of lower costs, better quality or } \\
\text { improved delivery times. }\end{array}$ & $\begin{array}{c}\text { Adopted } \\
\text { from Tallon } \\
\text { and } \\
\text { Pinsonneault } \\
\text { (2011) }\end{array}$ \\
\hline $\begin{array}{l}\text { Knowledge } \\
\text { acquisition }\end{array}$ & $\begin{array}{l}\text { The search for relevant information concerning the industry is an every-day } \\
\text { business in the company. }\end{array}$ & \multirow{4}{*}{$\begin{array}{l}\text { Adopted } \\
\text { from Flatten } \\
\text { et al. (2011) }\end{array}$} \\
\hline $\begin{array}{l}\text { Knowledge } \\
\text { assimilation }\end{array}$ & $\begin{array}{l}\text { In the company ideas and concepts are communicated cross-departmental. (e.g } \\
\text { the employees receive company's newsletters, business updates) }\end{array}$ & \\
\hline Transformation & $\begin{array}{l}\text { In the company there is a quick information flow. (e.g., if a business unit } \\
\text { obtains important information it communicates this information promptly to } \\
\text { all other business units or departments). } \\
\text { The employees can structure and use collected knowledge. ( e.g they can } \\
\text { contribute with process improvement ideas) } \\
\text { The employees are used to absorb new knowledge as well as to prepare it for } \\
\text { further purposes and to make it available. (e.g they attend various meetings } \\
\text { for project follow-ups) }\end{array}$ & \\
\hline $\begin{array}{l}\text { Knowledge } \\
\text { exploitation }\end{array}$ & $\begin{array}{l}\text { The employees successfully link existing knowledge with new insights. ( e.g } \\
\text { they contribute to ways-of-working for your daily responsibilities) } \\
\text { The company regularly reconsiders technologies and adapts them accordant to } \\
\text { the new knowledge. }\end{array}$ & \\
\hline $\begin{array}{l}\text { Company } \\
\text { performance }\end{array}$ & $\begin{array}{l}\text { The company is more profitable than its competitors. } \\
\text { The company's sales growth exceeds the one from the competition. } \\
\text { The company's revenue growth exceeds the one from the competition. } \\
\text { The market share growth exceeds the one from the competition. }\end{array}$ & $\begin{array}{l}\text { Adopted } \\
\text { from } \\
\text { Queiroz et al. } \\
\text { (2018) }\end{array}$ \\
\hline
\end{tabular}


Each of the variables has been addressed in the survey through various questions, all of them being measured with the Likert scale. The respondents had to select their options from the following significance list: 1- Strongly Disagree, 2-Disagree, 3-Undecided, 4- Agree, 5- Strongly agree.

Strategic agility has been measured by the respondents using a dedicated section of questions. As per Tallon and Pinsonneault (2011), these regarded responsiveness, business relationship and operations. Sambamurthy et al. (2003) have defined strategic agility as a measure of customer agility, partnering agility and operational agility. Thus, strategic agility is measured with qualitative feedback received from the 100 respondents. Responsiveness is measured with questions about changes in demand, innovation and price. Business partnerships are evaluated with supplier networking questions, while operational agility is measured through the reaction to market changes.

As mentioned under the literature section, absorptive capacity embeds four pillars: knowledge acquisition, knowledge assimilation, transformation and knowledge exploitation. The four dimensions have been tested in our survey with a set of questions adopted from Flatten et al. (2011). The authors have measured the four dimensions using a set of validated questions. A selection has been made out of all the questions, adopting them to the current research.

Knowledge acquisition is measured with the help of a question linked to its definition. The respondents are asked to evaluate the degree to which they believe their company is looking to obtain knowledge from external sources. Knowledge assimilation is measured by questioning the sample about their employer's ability to internally difuze the knowledge acquired externally.

As per Kale et al. (2019), transformation is measured as a link between knowledge assimilation and knowledge exploitation. Flatten et al. (2011) test the opinion of the sample on transformation with questions regarding speed, present and future vision on opportunities. Knowledge exploitation is defined by Kale et al. (2019) as an innovative item, so in the paper it is measured with questions adopted from Flatten et al. (2011) on new insights and novelty perspective.

Performance is measured using self-reported measures based on the perception received from the respondents. According to Queiroz et al. (2018) performance can be measured in two ways: self-reported measures and financial measures (ROA, ROI, net profit etc). For the purpose of this study it has been used the first approach. The self-reported measure of performance has been previously used by Ravichandran et al. (2005), asking the respondents to assess the company performance through a survey. Chen et al. (2014) agree with this measurement approach on performance. Tallon and Pinsonneault (2011) add that there is a positive relationship between strategic agility and company performance.

A multiple regression model is used in order to point out the relationship between two or more explanatory variables and a response variable to match a linear equation of the studied data. The regression contributes to deep dive on the influence of independent variables over the dependent one. This happens if the relationship is validated. To each value of the independent variables $\mathrm{x}$ we assign a value of the dependent variable $\mathrm{y}$. The population model for the multiple regression model relies on the y variable. We define the $y$ variable as 
being the company performance also known as the dependent variable, following the below general equation:

$$
\mathrm{y}_{\mathrm{i}}=\beta_{0}+\beta_{1} \mathrm{x}_{\mathrm{i}, 1}+\beta_{2} \mathrm{x}_{\mathrm{i}, 2}+\ldots . . \beta_{\mathrm{r}} \mathrm{x}_{\mathrm{i}, \mathrm{r}}+\varepsilon \mathrm{i}
$$

The equation has the following variables and parameters:

- $y_{i}=$ dependent variable

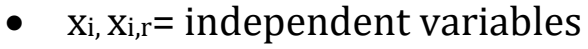

- $\beta 1, \beta r=$ regression coefficients

- $\varepsilon i=$ residual error

- $\mathrm{i}=$ unit of the population

Each of the $\beta$ coefficient is the change in the $Y$ related to a one-unit change in the independent variables. For the multiple regression the $\beta 1$ coefficient represents the change in $\mathrm{Y}$ related to a one-unit change in $\mathrm{x}_{1}$, when all other independent variables are constant. The residual value shows the difference between observed and predicted value of the $Y$ variable.

\section{Results}

\section{Sample characteristics}

This section is meant to provide an overview over the studied model and an interpretation of the outcome of the research. The results' interpretation is opened by analyzing the sample of the study. As shown in table 2, it has been outlined a capture of the sample's characteristics obtained through the survey questions.

After a careful look it has been noticed that most of the respondents are males with age ranging from 25 to 44 years old. The respondents are experienced professionals, as 86 per cent of the sample are seniors or have managerial roles as work experience. The sample is highly educated which is proved by the 98 per cent of respondents who have at least a Bachelor's degree, 41 per cent having also a Master's degree or having completed Ph.D studies.

Table 2. Summary of the sample

\begin{tabular}{|l|l|l|}
\hline & Frequency & Percent \\
\hline Gender & & \\
\hline Female & 32 & 0.32 \\
\hline Male & 68 & 0.68 \\
\hline Age & & \\
\hline $18-24$ & 10 & 0.1 \\
\hline $25-34$ & 34 & 0.34 \\
\hline $35-44$ & 42 & 0.42 \\
\hline $45-54$ & 13 & 0.13 \\
\hline $\begin{array}{l}54-65 \\
\text { Current Job } \\
\text { Experience }\end{array}$ & & 0.01 \\
\hline
\end{tabular}




\begin{tabular}{|l|l|l|}
\hline 1-3 Years & 41 & 0.41 \\
\hline 3-5 Years & 32 & 0.32 \\
\hline 5-10 Years & 18 & 0.18 \\
\hline 10-15 Years & 7 & 0.07 \\
\hline $\begin{array}{l}\text { Above 15 } \\
\text { Years }\end{array}$ & 2 & 0.02 \\
\hline $\begin{array}{l}\text { Seniority } \\
\text { level }\end{array}$ & 13 & 0.13 \\
\hline Entry & 35 & 0.35 \\
\hline Medium & 19 & 0.19 \\
\hline Senior & 32 & 0.32 \\
\hline $\begin{array}{l}\text { Managerial/ } \\
\text { Leadership }\end{array}$ & 1 & 0.01 \\
\hline Executive & 51 & 0.51 \\
\hline Studies & 1 & 0.07 \\
\hline Highschool & 1 & 0.41 \\
\hline $\begin{array}{l}\text { Bachelor's } \\
\text { degree } \\
\text { Master's }\end{array}$ & 51 \\
\hline PhD & 19 \\
\hline
\end{tabular}

Source: Authors' own computation

\section{Regression analysis of performance}

A multiple regression model is applied to find out if the selected variables are significant for the dependent variable, company performance. For this it has been used the Enter method for regression. The linear regression is used to check if company performance can be predicted using as framework strategic agility and absorptive capacity. The least variable is composed by four layers: knowledge acquisition, knowledge assimilation, transformation, knowledge exploitation. Therefore, the multiple linear regression model of the paper will follow the below equation:

Performance $=\beta_{0}+\beta_{1} *$ Strategic agility $+\beta_{2} *$ Knowledge acquisition $+\beta_{3} *$ Knowledge assimilation $+\beta_{4} *$ Transformation $+\beta_{5} *$ Knowledge exploitation $+\varepsilon i$

In order to make sure that a valid outcome will be obtained, and a linear regression is followed, firstly it has been deployed a Pearson's correlations analysis. The results can be observed in table 3 below: 
Table 3. Pearson's Correlations

\begin{tabular}{|c|c|c|c|c|c|c|c|}
\hline & & $\begin{array}{l}\text { Company } \\
\text { performance }\end{array}$ & $\begin{array}{l}\text { Strategic } \\
\text { agility }\end{array}$ & $\begin{array}{l}\text { Knowledge } \\
\text { acquisition }\end{array}$ & $\begin{array}{l}\text { Knowledge } \\
\text { assimilation }\end{array}$ & $\begin{array}{l}\text { Transfor } \\
\text { mation }\end{array}$ & $\begin{array}{l}\text { Knowledge } \\
\text { exploitation }\end{array}$ \\
\hline \multirow{3}{*}{$\begin{array}{l}\text { Company } \\
\text { performance }\end{array}$} & \begin{tabular}{|l|} 
Pearson \\
Correlati \\
on \\
\end{tabular} & 1 & $.556^{* *}$ & $.327^{* *}$ & $.236^{*}$ & $.532 * *$ & $.300^{* *}$ \\
\hline & \begin{tabular}{|l|} 
Sig. (2- \\
tailed)
\end{tabular} & & .000 & .001 & .018 & .000 & .002 \\
\hline & $\mathrm{N}$ & 100 & 100 & 100 & 100 & 100 & 100 \\
\hline \multirow[t]{3}{*}{ Strategic agility } & $\begin{array}{l}\text { Pearson } \\
\text { Correlati } \\
\text { on } \\
\end{array}$ & $.556^{* *}$ & 1 & -.069 & $.272^{* *}$ & $.416^{* *}$ & .062 \\
\hline & $\begin{array}{l}\text { Sig. (2- } \\
\text { tailed) }\end{array}$ & .000 & & .498 & .006 & .000 & .542 \\
\hline & $\mathrm{N}$ & 100 & 100 & 100 & 100 & 100 & 100 \\
\hline \multirow{3}{*}{$\begin{array}{l}\text { Knowledge } \\
\text { acquisition }\end{array}$} & $\begin{array}{l}\text { Pearson } \\
\text { Correlati } \\
\text { on }\end{array}$ & $.327^{* *}$ & -.069 & 1 & .093 & $.278^{* *}$ & $.329^{* *}$ \\
\hline & $\begin{array}{l}\text { Sig. (2- } \\
\text { tailed) }\end{array}$ & .001 & .498 & & .358 & .005 & .001 \\
\hline & $\mathrm{N}$ & 100 & 100 & 100 & 100 & 100 & 100 \\
\hline \multirow{3}{*}{$\begin{array}{l}\text { Knowledge } \\
\text { assimilation }\end{array}$} & \begin{tabular}{|l} 
Pearson \\
Correlati \\
on \\
\end{tabular} & $.236^{*}$ & $.272^{* *}$ & .093 & 1 & .183 & $.230^{*}$ \\
\hline & $\begin{array}{l}\text { Sig. (2- } \\
\text { tailed) } \\
\end{array}$ & .018 & .006 & .358 & & .068 & .021 \\
\hline & $\mathrm{N}$ & 100 & 100 & 100 & 100 & 100 & 100 \\
\hline \multirow[t]{3}{*}{ Transformation } & \begin{tabular}{|l|} 
Pearson \\
Correlati \\
on
\end{tabular} & $.532^{* *}$ & $.416^{* *}$ & $.278^{* *}$ & .183 & 1 & $.246^{*}$ \\
\hline & \begin{tabular}{|l|} 
Sig. (2- \\
tailed)
\end{tabular} & .000 & .000 & .005 & .068 & & .014 \\
\hline & $\mathrm{N}$ & 100 & 100 & 100 & 100 & 100 & 100 \\
\hline \multirow{3}{*}{$\begin{array}{l}\text { Knowledge } \\
\text { exploitation }\end{array}$} & \begin{tabular}{|l|} 
Pearson \\
Correlati \\
on \\
\end{tabular} & $.300^{* *}$ & .062 & $.329^{* *}$ & $.230^{*}$ & $.246^{*}$ & 1 \\
\hline & $\begin{array}{l}\text { Sig. (2- } \\
\text { tailed) }\end{array}$ & .002 & .542 & .001 & .021 & .014 & \\
\hline & $\mathrm{N}$ & 100 & 100 & 100 & 100 & 100 & 100 \\
\hline
\end{tabular}

Note: **. Correlation is significant at the 0.01 level (two-tailed).

*. Correlation is significant at the 0.05 level (two-tailed).

Source: Authors' own computation

Analyzing the output of the table above there are two indicators to consider for the sample: Pearson's correlation and Sig. (2-tailed), cumulating a total of 100 responses. Pearson's correlation shows how strong the relationship of the tested variables is, while Sig. 
(2-tailed) represents the significance value. The chosen level of significance for comparison for our study is 0.05 . Thus, if the sample's significance level is greater than 0.05 then the correlation occurs by chance. If the values are lower than 0.05 , then there is proof that the resulted correlations do not belong to the population.

Further on, it has been noticed that many of the variables are significantly correlated. This means that these correlations are significant. The significant identified correlations are as follows: performance and strategic agility, performance and knowledge acquisition, performance and knowledge exploitation, strategic agility and knowledge assimilation, strategic agility and transformation, knowledge acquisition and knowledge assimilation. Out of the mentioned correlations, the following are the strongest: company performance and knowledge acquisition, company performance and transformation, strategic agility and company performance, strategic agility and transformation. The correlation indicates that if one variable will increase in value, the other corresponding correlated one will increase too. The correlations previously mentioned have the corresponding significance value lower than 0.05 , so one can say that the correlations are statistically significant.

Analyzing the below model of the regression in table 4, the R Square indicator shows the percentage of variance of the dependent variable explained by the independent variable. Checking the model, the R Square indicates $50.6 \%$ of the overall variance. The adjusted $\mathrm{R}$ Square considers the sample size, while the Standard Error measures the variability of actual $\mathrm{Y}$ values, in our case company performance. Looking at the Durbin-Watson result, the obtained value of 1.758 belongs to the interval $(1.5 ; 2.5)$ of critical values. This indicates that the model has a positive autocorrelation.

Table 4. Model Summary for strategic agility

\begin{tabular}{|l|l|l|l|l|l|}
\hline Model & R & R Square & $\begin{array}{l}\text { Adjusted R } \\
\text { Square }\end{array}$ & $\begin{array}{l}\text { Std. Error of } \\
\text { the Estimate }\end{array}$ & $\begin{array}{l}\text { Durbin- } \\
\text { Watson }\end{array}$ \\
\hline 1 & .712 & .506 & .480 & .864 & 1.758 \\
\hline
\end{tabular}

Note: Predictors: (Constant), Knowledge exploitation, Strategic agility, Knowledge acquisition, Knowledge assimilation, Transformation

Dependent Variable: Company performance

Source: Authors' own computation

As observed below in table 5, the ANOVA results strengthen the fact that the model has a good fit $(F=14.398, p<0.05)$. One can see that Sig. is smaller than 0.05 , so the model is significant. The ANOVA results also outline that the variables are significant predictors for performance.

Table 5. ANOVA results for strategic agility

\begin{tabular}{|cl|l|l|l|l|l|}
\hline Model & $\begin{array}{l}\text { Sum of } \\
\text { Squares }\end{array}$ & df & Mean Square & F & Sig. \\
\hline \multirow{2}{*}{ Regression } & 71.991 & 5 & 14.398 & 19.288 & .000 \\
\cline { 2 - 7 } & Residual & 70.169 & 94 & .746 & & \\
\cline { 2 - 7 } & Total & 142.160 & 99 & & & \\
\hline
\end{tabular}

Note: Predictors: (Constant), Knowledge exploitation, Strategic agility, Knowledge acquisition, Knowledge assimilation, Transformation Dependent Variable: Company performance 
The coefficients table shows how well the variables predict the dependent variable, company performance. The coefficients from table 6 below indicate that strategic agility $(b=0.427, p<0.05)$, knowledge acquisition $(b=0.295, p<0.05)$ and transformation $(b=0.244$, $\mathrm{p}<0.05$ ) are significant and positive predictors for company performance. Additionally, for the regression model, a 1-unit increase in strategic agility will result in a 0.427 increase in company performance, a 1-unit increase in knowledge acquisition will result in 0.295 in company performance, while a 1-unit increase in transformation will result in a 0.244 increase in company performance. Therefore, hypotheses 1,2 and 4 have been confirmed. On the other hand, it has been noticed that neither knowledge assimilation, or knowledge exploitation can predict company performance, thus hypothesis 3 and 5 must be rejected.

Note: Dependent Variable: Company performance

Source: Authors' own computation

The standardized beta values indicate that strategic agility $(\beta=0.463, \mathrm{t}(100)=5.518)$

\begin{tabular}{|c|c|c|c|c|c|c|c|c|c|}
\hline & \multicolumn{2}{|c|}{$\begin{array}{l}\text { Unstandardized } \\
\text { Coefficients }\end{array}$} & \multirow{2}{*}{$\begin{array}{l}\text { Standardized } \\
\text { Coefficients } \\
\text { Beta }\end{array}$} & \multirow[b]{2}{*}{ t } & \multirow[b]{2}{*}{ Sig. } & \multicolumn{2}{|c|}{$\begin{array}{l}95.0 \% \\
\text { Confidence } \\
\text { Interval for B }\end{array}$} & \multicolumn{2}{|c|}{$\begin{array}{l}\text { Collinearity } \\
\text { Statistics }\end{array}$} \\
\hline & B & $\begin{array}{l}\text { Std. } \\
\text { Error }\end{array}$ & & & & $\begin{array}{l}\text { Lower } \\
\text { Bound }\end{array}$ & $\begin{array}{l}\text { Upper } \\
\text { Bound }\end{array}$ & Tolerance & VIF \\
\hline (Constant) & $\begin{array}{l}- \\
1.089\end{array}$ & .652 & & -1.671 & .098 & -2.382 & & & \\
\hline $\begin{array}{l}\text { H1: Strategic } \\
\text { agility }\end{array}$ & .427 & .077 & .463 & 5.518 & .000 & .274 & .581 & .746 & 1.341 \\
\hline $\begin{array}{l}\text { H2: Knowledge } \\
\text { acquisition }\end{array}$ & .295 & .095 & .249 & 3.097 & .003 & .106 & .484 & .813 & 1.230 \\
\hline $\begin{array}{l}\text { H3: Knowledge } \\
\text { assimilation }\end{array}$ & .018 & .099 & .014 & .180 & .858 & -.179 & .214 & .878 & 1.139 \\
\hline $\begin{array}{l}\text { H4: } \\
\text { Transformation }\end{array}$ & .244 & .088 & .236 & 2.760 & .007 & .068 & .419 & .716 & 1.396 \\
\hline $\begin{array}{l}\text { H5: Knowledge } \\
\text { exploitation }\end{array}$ & .211 & .130 & .129 & 1.622 & .108 & -.047 & .469 & .834 & 1.199 \\
\hline
\end{tabular}

and knowledge acquisition $(\beta=0.249, \mathrm{t}(100)=3.097)$ have the highest impact on company performance. The VIF values (variance inflation factor) outlined under collinearity statistics are close to 1 . These show that there is no collinearity between the independent variables. The results confirm that in the paper's regression model all the predictor variables can predict in an independent manner the value of the dependent variable.

In order to have a full overview of the research, there has been designed a summary of the analysis illustrated below by table 7. It concludes the findings of the research for each of the five hypotheses, enabling a hypotheses' summary to understand which of these are supported and which are rejected.

Table 7. Research results

\begin{tabular}{|l|l|l|l|l|}
\hline Hypothesis & Description & Variable & Coefficient & Findings \\
\hline H1: & $\begin{array}{l}\text { Strategic agility is positively related to } \\
\text { company performance. }\end{array}$ & Strategic agility & .427 & $\begin{array}{l}\mathrm{p}<0.05, \\
\text { supported }\end{array}$ \\
\hline
\end{tabular}




\begin{tabular}{|l|l|l|l|l|}
\hline H2: & $\begin{array}{l}\text { Knowledge acquisition is positively related } \\
\text { to company performance. }\end{array}$ & Aquisition & .295 & $\begin{array}{l}\mathrm{p}<0.05, \\
\text { supported }\end{array}$ \\
\hline H3: & $\begin{array}{l}\text { The higher the knowledge assimilation is, the } \\
\text { higher the company performance is. }\end{array}$ & $\begin{array}{l}\text { Knowledge } \\
\text { assimilation }\end{array}$ & .018 & $\begin{array}{l}\mathrm{p}>0.05, \\
\text { rejected }\end{array}$ \\
\hline H4: & $\begin{array}{l}\text { The higher the transformation is, the higher } \\
\text { the performance is. }\end{array}$ & Transformation & .244 & $\begin{array}{l}\mathrm{p}<0.05, \\
\text { supported }\end{array}$ \\
\hline & $\begin{array}{l}\text { There is a statistically significant effect of the } \\
\text { knowledge exploitation on the company's } \\
\text { performance. }\end{array}$ & $\begin{array}{l}\text { Knowledge } \\
\text { exploitation }\end{array}$ & .211 & $\begin{array}{l}\mathrm{p}>0.05, \\
\text { rejected }\end{array}$ \\
\hline
\end{tabular}

Source: Authors' own computation

\section{Discussion}

The research points out the key factors out of five studied variables leading to company performance. With the support of primary research, the responses gathered show the respondents' perception over the topics covered in the paper. Step by step, there have been identified valuable insights of the IT industry from various stakeholders as their opinion has been collected, tested and validated with literature. Across the study there is a continuous search for matching the literature with the opinion of stakeholders of the IT sector. As a takeaway, this means that there are strong connections between the industry and the literature.

Out of the five independent variables included in the model, the results indicate that only three of them influence company performance. The research shows that strategic agility, knowledge acquisition and transformation have a high influence on company performance. Out of the three identified factors determining company performance, strategic agility has the strongest impact. This confirms the results of Tallon et al. (2011) who pointed out that strategic agility is positively associated with company performance. The first hypothesis is also in line with Quiroz et. al (2018) who believe in the IT sector strategic agility has a positive influence on company performance. The same view is shared by Kale et al. (2018) who show that strategic agility is positively affecting company performance. The authors add that strategic agility is a connector between the four layers of absorptive capacity and company performance. Doz (2019) strengthens the paper's findings, as the authors consider that in the IT industry, strategic agility is a major factor of influence for company performance.

As per paper's findings, knowledge acquisition is the second-strongest impact factor on company performance. A 1-unit increase in knowledge acquisition will lead to 0.295 increase in company performance. The result is aligned to Pearson's strong correlation between knowledge acquisition and company performance. Our hypothesis is confirmed by Kale et al. (2018) who consider knowledge acquisition influences company performance. The authors describe knowledge acquisition as a dimension of absorptive capacity, having an indirect effect on performance. Our results contradict that knowledge acquisition as being an indirect factor of influence for company performance. The research points out that knowledge acquisition is directly influencing strategic agility as proved by our findings. Our analysis points out knowledge acquisition has a strong impact on company performance. Navarro et al. (2016) confirms the paper's findings on the knowledge acquisition dimension. The authors consider knowledge acquisition is a contributing factor to increased company performance. 
The paper's results indicate that the third validated factor of influence for company performance is transformation. This view is confirmed by Shin et al. (2015) who state that transformation has a positive influence over company performance. Hacklin et al. (2018) also support that transformation plays an important role in achieving company performance. Ali et al. (2016) state that transformation is a booster for increased company performance. As per our findings outlined in table 3, the Pearson's correlation result shows that there is a strong positive correlation between transformation and company performance, sustained by the fact that hypothesis 4 is supported, meaning the higher the transformation will be, the higher the company performance will be. Battistella et al. (2017) confirm these results, mentioning that transformation enables increased performance in an organization.

In what regards the knowledge assimilation and knowledge exploitation dimensions of the model, the two corresponding hypotheses have been rejected. In the case of knowledge assimilation, the results contradict Baker et al. (2017) who claim that the faster one assimilates external knowledge, the faster the company performance will increase. The last hypothesis regarding knowledge exploitation has also been rejected. This is aligned with Teece (2018) who consider that the company performance is increased not only through exploiting new opportunities, but by implementing and monitoring them.

Looking at the current economic and cultural background for the IT industry in Romania, there is a high focus for growth and development. The IT industry is one of the main pillars of the economy, bringing new business and cultural opportunities on the market. According to Invest Romania, a Romanian governmental organization for foreign investment, the IT industry value in Romania will reach in 20206.4 billion EUR. The economic and cultural context in Romania indicates why strategic agility, knowledge acquisition and transformation have been confirmed as major factors of company performance of the Romanian IT industry.

An example which illustrates the three validated factors refers to a Governmental incentive applied in Romania for the IT industry. Its implementation had economic, cultural and business implications. Starting 2001, Romania has introduced a fiscal measure by which IT employees holding a Computer Science degree are exempted for paying income tax. According to ANIS (Romanian Employers' Association of Software and IT Services) after 20 year, in 2020 the IT industry in Romania contributes to 6 per cent of the GDP value in Romania, result delivered by 2.2 per cent of the total employed people in Romania. This has been a strategic incentive, confirming the high potential for strategic agility for IT in Romania. The income tax exemption has generated a high transformation on the market, opening new opportunities for the IT business environment which resulted in a high focus for knowledge acquisition. The outcome of this strategic incentive led to a continuous change and increased company performance within the IT industry. Knowledge assimilation and knowledge exploitation have been rejected as per the paper's results, but further research can be conducted to understand and investigate why these two hypotheses have not been confirmed.

In summary, the paper managed to identify which of the five hypotheses are supported and have as takeaway three validated factors for company performance. Strategic agility, knowledge acquisition and transformation are the three factors determining company performance in the case of the IT industry in Romania. Future research can analyze whether this applies to other industries or other countries. 


\section{Conclusions}

The paper identifies which are the key factors that determine company performance. It points out which and to what level are these influencing company performance for IT companies. The results of the multiple regression highlight that strategic agility, knowledge acquisition and transformation are significant and positive predictors of company performance. Our study contributes to the literature through the knowledge characteristics analysis of the IT stakeholders operating in Romania and their beliefs towards strategic agility and company performance.

Out of the five hypotheses about strategic agility, the paper concludes that three are supported and in line with the literature. It proves that companies must have a high focus on the dynamics of the business environment, their performance being connected to strategic agility, knowledge acquisition and transformation. The IT companies face a high level of competition on the market; thus, they must be up to date with the industry's trends and market moves.

The paper also has limitations, one of them referring to the sample' size. As actions for improvements, for a more in-depth analysis in the future there can be collected an increased number of responses, to have a broader view over the studied concepts. As some of the hypotheses have been rejected, for the future it can also be organized a series of interviews for a better understanding of the opinion of the stakeholders of IT companies.

\section{References:}

Alahyari, H., Svensson, R. B., \& Gorschek, T. (2017). A study of value in agile software development organizations. Journal of Systems and Software, Vol. 125, pp. 271-288.

Ali, M., Kan, K. A. S., \& Sarstedt, M. (2016). Direct and configurational paths of absorptive capacity and organizational innovation to successful organizational performance. Journal of Business Research, Vol. 69, No.11, pp. 5317-5323.

Ammar, 0., \& Chereau, P. (2018). Business model innovation from the strategic posture perspective: An exploration in manufacturing SMEs. European Business Review, Vol. 30, No. 1, pp. 38-65.

Battistella, C., De Toni, A. F., De Zan, G., \& Pessot, E. (2017). Cultivating business model agility through focused capabilities: A multiple case study. Journal of Business Research, Vol. 73, pp. 65-82.

Bolívar-Ramos, M. T., García-Morales, V. J., \& Martín-Rojas, R. (2013). The effects of Information Technology on absorptive capacity and organizational performance. Technology Analysis \& Strategic Management, Vol. 25, No. 8, pp. 905922.

Bolisani, E., \& Bratianu, C. (2018). Knowledge as a strategic weapon. Emergent knowledge strategies, Vol. 4, pp. 49-72.

Bratianu, C., \&amp; Bolisani, E. (2015). Knowledge strategy: An integrated approach for managing uncertainty. European Conference on Knowledge Management Academic Conferences International Limited, Vol. 18, No. 1, pp. 169-177.

Bratianu, C. (Ed.). (2015). Organizational Knowledge Dynamics: Managing Knowledge Creation, Knowledge acquisition, Sharing, and Transformation: Managing Knowledge Creation, Knowledge acquisition, Sharing, and Transformation, IGI Global, pp. 235236 
Cegarra-Navarro, J. G., Soto-Acosta, P., \& Wensley, A. K. (2016). Structured knowledge processes and firm performance: The role of organizational agility. Journal of Business Research, Vol. 69, No. 5, pp. 1544-1549.

Chae, H. C., Koh, C. E., \& Park, K. O. (2018). Information technology capability and firm performance: Role of industry. Information \& Management, Vol. 55, No. 5, pp. 525546.

Chen, Y., Wang, Y., Nevo, S., Jin, J., Wang, L., \& Chow, W. S. (2014). IT capability and organizational performance: the roles of business process agility and environmental factors. European Journal of Information Systems, 23(3), pp. 326-342.

Di Minin, A., Frattini, F., Bianchi, M., Bortoluzzi, G., \& Piccaluga, A. (2014). Udinese Calcio soccer club as a talents factory: Strategic agility, diverging objectives, and resource constraints. European Management Journal, Vol. 32, No. 2, pp. 319-336.

Doz, Y. L., \& Kosonen, M. (2010). Embedding strategic agility: A leadership agenda for accelerating business model renewal. Long range planning, Vol. 43, No.2, pp. 370382.

Doz, Y. (2019). Fostering strategic agility: How individual executives and human resource practices contribute. Human Resource Management Review, pp. 1-4.

Flatten, T. C., Greve, G. I., \& Brettel, M. (2011). Absorptive capacity and firm performance in SMEs: The mediating influence of strategic alliances. European Management Review, Vol. 8, No. 3, pp. 137-152.

Flatten, T. C., Engelen, A., Zahra, S. A., \& Brettel, M. (2011). A measure of absorptive capacity: Scale development and validation. European Management Journal, Vol. 29, No. 2, pp. 98-116.

Kale, E., Aknar, A., \& Başar, Ö. (2019). Absorptive capacity and firm performance: The mediating role of strategic agility. International Journal of Hospitality Management, Vol. 78, pp. 276-283.

Kale, E., Aknar, A., \& Başar, Ö. (2018). Absorptive capacity and firm performance: The mediating role of strategic agility. International Journal of Hospitality Management, Vol. 76, pp. 77-96.

García-Morales, V. J., Ruiz-Moreno, A., \& Llorens-Montes, F. J. (2007). Effects of technology absorptive capacity and technology proactivity on organizational learning, innovation and performance: An empirical examination. Technology Analysis \& Strategic Management, Vol.19, No. 4, pp. 527-558.

Hacklin, F., Björkdahl, J., \& Wallin, M. W. (2018). Strategies for business model innovation: How firms reel in migrating value. Long range planning, Vol. 51, No. 1, pp. 82-110.

Illenberger, J., \& Flötteröd, G. (2012). Estimating network properties from snowball sampled data. Social Networks, Vol. 34, No. 4, pp. 701-711.

Junni, P., Sarala, R. M., Tarba, S. Y., \& Weber, Y. (2015). The role of strategic agility in knowledge acquisitions. British Journal of Management, Vol. 26, No. 4, pp. 596-616.

Kim, M., \& Chai, S. (2017). The impact of supplier innovativeness, information sharing and strategic sourcing on improving supply chain agility: Global supply chain perspective. International Journal of Production Economics, Vol. 187, pp. 42-52.

McIver, D., Lengnick-Hall, M. L., \& Lengnick-Hall, C. A. (2018). A strategic approach to workforce analytics: Integrating science and agility. Business Horizons, Vol. 61, No. 3, pp. 397-407. 
Nemkova, E. (2017). The impact of agility on the market performance of born-global firms: an exploratory study of the 'Tech City'innovation cluster. Journal of Business Research, Vol. 80, pp. 257-265.

Lavie, D., \& Rosenkopf, L. (2006). Balancing exploration and knowledge exploitation in alliance formation. Academy of management journal, Vol. 49, No. 4, pp. 797-818.

Lane, P. J., Salk, J. E., \& Lyles, M. A. (2001). Absorptive capacity, learning, and performance in international joint ventures. Strategic management journal, Vol. 22, No. 12, pp. 11391161.

Oyedijo, A. (2012). Strategic agility and competitive performance in the Nigerian telecommunication industry: an empirical investigation. American International Journal of Contemporary Research, Vol. 2, No. 3, pp. 227-237.

Păunescu, C., Popescu, M., \& Duennweber, M. (2018a). Factors Determining Desirability of Entrepreneurship in Romania. Sustainability, Vol. 10, No. 11, pp. 1-22.

Păunescu, C., Argatu, R., \& Lungu, M. (2018b). Implementation of ISO 22000 in Romanian companies: Motivations, difficulties and key benefits. Amfiteatru Economic, Vol. 20, No. 47, pp. 30-45.

Păunescu, C., Popescu, M. C., \& Blid, L. (2018c). Business impact analysis for business continuity: Evidence from Romanian enterprises on critical functions. Management \& Marketing. Challenges for the Knowledge Society, Vol. 13, No. 3, pp. 1035-1050.

Queiroz, M., Tallon, P. P., Sharma, R., \& Coltman, T. (2018). The role of IT application orchestration capability in improving agility and performance. The Journal of Strategic Information Systems, Vol. 27, No. 1, pp. 4-21.

Ravichandran, T., Lertwongsatien, C., \& Lertwongsatien, C. (2005). Effect of information systems resources and capabilities on firm performance: A resource-based perspective. Journal of management information systems, 21(4), pp. 237-276.

Sambamurthy, V., Bharadwaj, A., \& Grover, V. (2003). Shaping agility through digital options: Reconceptualizing the role of information technology in contemporary firms. MIS quarterly, Vol. 27, No. 2, pp. 237-263.

Shin, H., Lee, J. N., Kim, D., \& Rhim, H. (2015). Strategic agility of Korean small and medium enterprises and its influence on operational and firm performance. International Journal of Production Economics, Vol. 168, pp. 181-196.

Srivastava, A. K., \& Sushil. (2013). Modeling strategic performance factors for effective strategy execution. International Journal of Productivity and Performance Management, Vol. 62, No. 6, pp. 554-582.

Taherdoost, H. (2016). How to Design and Create an Effective Survey/Questionnaire; A Step by Step Guide. International Journal of Academic Research in Management, Vol. 5, No.4, pp. 37-41.

Tallon, P. P., \& Pinsonneault, A. (2011). Competing perspectives on the link between strategic information technology alignment and organizational agility: insights from a mediation model. Mis Quarterly, Vol. 35, No. 2, pp. 463-486.

Teece, D. J. (2018). Business models and dynamic capabilities. Long Range Planning, Vol. 51, No. 1 , pp. 40-49.

Vecchiato, R. (2015). Creating value through foresight: First mover advantages and strategic agility. Technological Forecasting and Social Change, Vol. 101, pp. 25-36. 
Weber, Y., \& Tarba, S. Y. (2014). Strategic agility: A state of the art introduction to the special section on strategic agility. California Management Review, Vol. 56, No. 3, pp. 5-12.

Wilden, R., Gudergan, S. P., Nielsen, B. B., \& Lings, I. (2013). Dynamic capabilities and performance: strategy, structure and environment. Long Range Planning, Vol. 46, No. 1, pp. 72-96.

Wright, R., \& Stein, M. (2005). Snowball sampling. Encyclopedia of Social Measurement, Vol. 3, pp. 495-500.

Yang, C., \& Liu, H. M. (2012). Boosting firm performance via enterprise agility and network structure. Management Decision, Vol. 50, No. 6, pp. 1022-1044.

Zahra, S. A., Sapienza, H. J., \& Davidsson, P. (2006). Entrepreneurship and dynamic capabilities: A review, model and research agenda. Journal of Management studies, Vol. 43, No. 4, pp. 917-955. 